\title{
Article \\ Selection and Validation of Reference Genes for Quantitative RT-PCR Analysis in Corylus heterophylla Fisch. $\times$ Corylus avellana $\mathrm{L}$.
}

\author{
Sihao Hou ${ }^{1,2,3,+}$, Tiantian Zhao ${ }^{1,2,3,+}$, Dan Yang ${ }^{1,2,3}$, Qing Li ${ }^{1,2,3}$, Lisong Liang ${ }^{1,2,3}$, Guixi Wang ${ }^{1,2,3}$ and \\ Qinghua Ma ${ }^{1,2,3, *}$
}

check for

updates

Citation: Hou, S.; Zhao, T.; Yang, D.; Li, Q.; Liang, L.; Wang, G.; Ma, Q.

Selection and Validation of Reference Genes for Quantitative RT-PCR Analysis in Corylus heterophylla Fisch. $\times$ Corylus avellana L. Plants 2021, 10, 159. https://doi.org/10.3390/ plants10010159

Received: 8 December 2020 Accepted: 8 January 2021 Published: 15 January 2021

Publisher's Note: MDPI stays neutral with regard to jurisdictional clai$\mathrm{ms}$ in published maps and institutional affiliations.

\section{Copyright: ( 2021 by the authors. Li-} censee MDPI, Basel, Switzerland. This article is an open access article distributed under the terms and conditions of the Creative Commons Attribution (CC BY) license (https:// creativecommons.org/licenses/by/ $4.0 /)$.
1 Key Laboratory of Tree Breeding and Cultivation of the State Forestry and Grassland Administration, Research Institute of Forestry, Chinese Academy of Forestry, Beijing 100091, China; HSH@caf.ac.cn (S.H.); ztt@caf.ac.cn (T.Z.); YD@caf.ac.cn (D.Y.); LQ@caf.ac.cn (Q.L.); lianglisong@caf.ac.cn (L.L.); WGX@caf.ac.cn (G.W.)

2 Hazelnut Engineering and Technical Research Center of the State Forestry and Grassland Administration, Beijing 100091, China

3 National Hazelnut Industry Innovation Alliance of the State Forestry and Grassland Administration, Beijing 100091, China

* Correspondence: mqhmary@caf.ac.cn; Tel.: +86-1381-139-0689

+ Both authors contributed equally to this work.

\begin{abstract}
Background: the species of Corylus have sporophytic type of self-incompatibility. Several genes related to recognition reaction between pollen and stigma have been identified in hazelnuts. To better understand the self-incompatibility (SI) response, we screened the suitable reference genes by using quantitative real-time reverse transcription PCR (qRT-PCR) analysis in hazelnut for the first time. (2) Methods: the major cultivar "Dawei" was used as material. A total of 12 candidate genes were identified and their expression profiles were compared among different tissues and in response to various treatments (different times after self- and cross-pollination) by RT-qPCR. The expression stability of these 12 candidate reference genes was evaluated using geNorm, NormFinder, BestKeeper, Delta Ct, and RefFinder programs. (3) Results: the comprehensive ranking of RefFinder indicated that ChaActin, VvActin, ChaUBQ14, and ChaEF1- $\alpha$ were the most suitable reference genes. According to the stability analysis of 12 candidate reference genes for each sample group based on four software packages, ChaActin and ChaEF1- $\alpha$ were most stable in different times after self-pollination and $4 \mathrm{~h}$ after self- and cross-pollination, respectively. To further validate the suitability of the reference genes identified in this study, CavPrx, which the expression profiles in Corylus have been reported, was quantified by using ChaActin and ChaEF1- $\alpha$ as reference genes. (4) Conclusions: our study of reference genes selection in hazelnut shows that the two reference genes, ChaActin and ChaEF1- $\alpha$, are suitable for the evaluation of gene expression, and can be used for the analysis of pollen-pistil interaction in Corylus. The results supply a reliable foundation for accurate gene quantifications in Corylus species, which will facilitate the studies related to the reproductive biology in Corylus.
\end{abstract}

Keywords: Ping'ou hybrid hazelnut (C. heterophylla Fisch. $\times$ C. avellana L.); real-time quantitative PCR; reference gene; stability of gene expression; self-incompatibility

\section{Introduction}

Hazelnut (Corylus), a member of the birch family (Betulaceae) in the order Fagales, is one of the most important nut crops and a woody oil plant, with high economic and nutritional value. To date, around 25 species of Corylus have been described by taxonomists, among which 13 are widely-recognized [1,2]. The various species of hazelnut are primarily distributed across the temperate zones of the Northern Hemisphere [3], with Asia, Europe, and North America. Among them, only some cultivars of European hazelnut (C. avellana) have been commercialized [4,5]. Approximately eight species and two varieties of Corylus 
are native to China, and are widely-distributed across 24 provinces. The main commercial cultivars are several types of Ping'ou hybrid hazelnuts, obtained by artificial interspecific hybridization of the Ping hazelnut (C. heterophylla) with European hazelnut [6,7].

According to world Corylus resources, world hazelnut species exhibit abundant characteristics, such as tree features, nut characteristics, stress resistance, and self-incompatibility, deserving more investigation and application. Hazelnut researchers are currently focusing on breeding for Eastern Filbert Blight resistance in European hazelnut [8,9], S-locus gene identification and distribution among cultivars and species [10,11], and cold-resistance breeding of interspecies hybrids with some wild species as the female parent $[12,13]$. As these studies progress, the use of molecular biotechnology is of great significance for the identification of trait-specific genes and molecular-assisted breeding in hazelnut.

Quantitative real-time polymerase chain reaction (RT-qPCR) is among the most common methods used for gene expression and transcriptome analysis. It refers to an improved PCR technique, which uses fluorescent probes and fluorescent dyes in the reaction system, and is characterized by high sensitivity and specificity, good reproducibility, a wide dynamic quantification range, and high-throughput capacity for a limited number of target genes [14]. RT-qPCR is a powerful tool for RNA analysis, conducted using cDNA template, which is generated from RNA. The initial RNA quantity, purity, and the efficiencies of reverse transcription and amplification, all affect the accuracy of gene expression analysis by RT-qPCR $[15,16]$. Reference genes are commonly used for standardization, to minimize experimental error [16]. Increasing studies have shown that an ideal reference gene is expressed stably, or relatively stable, regardless of tissue or cell type, and in the presence of various test environments and influencing factors [17-19]. Traditional reference genes, such as actin $(A C T)$, glyceraldehyde-3-phosphate dehydrogenase (GAPDH), ubiquitin (UBQ), and $18 S$ rRNA have been tested in previous investigations. However, variations in the expression levels of reference genes have been reported in different tissues and/or in response to experimental treatments. Therefore, it is a challenge for RT-qPCR to identify a set of reference genes whose mRNA expression levels do not change significantly across tissues, independently of the experimental context [20]. In most cases, validation of reference genes is determined using statistical approaches, such as geNorm [21], NormFinder [22], BestKeeper [23], and Delta Ct [24].

Hazelnuts are monoecious, wind-pollinated, and self-incompatible. Reproduction is restricted by a sporophytic self-incompatibility system, which is controlled by a single locus with various S-alleles determining compatibility [25]. Self-incompatibility is considered to be an evolutionary advantage, but it is also a limiting factor for obtaining a commercial yield in hazelnut, since it restricts the choice of some cultivars that can be used in the same plantation. Consequently, knowledge of specific S-alleles associated with each cultivar, as well as the type of genetic control of incompatibility would greatly facilitate the choice of successful parental combinations. Several self-incompatibility-related genes to date have been identified in hazelnut [26-28]. However, there are no reports of systematic identification of reference genes suitable for use in the evaluation of self-incompatibilityrelated genes in RT-qPCR expression studies. Thus, the identification of reliable reference genes for use in RT-qPCR will benefit further studies using this mature technology by reducing costs. Furthermore, the using of appropriate reference genes facilitates more accurate calculation of gene expression levels and provides a useful resource for future research. In this study, the expression stability of 12 candidate reference genes, selected based on transcriptome data from the Ping'ou hybrid hazelnut and previous studies, was analyzed by RT-qPCR in different plant materials, using four statistical algorithms for reference gene detection. The objective of this study was to validate suitable reference genes, which may help to facilitate subsequent studies of the expression profiles of selfincompatibility related genes. 


\section{Results}

\subsection{Identification of Candidate Reference Genes and Primer Specificity and Efficiency}

According to the filtering criteria (False Discovery Rate (FDR) $<0.01$ and Log2 ratio between -1 and 1) mentioned in the Materials and Methods, three candidate reference genes were selected from the transcriptome database, based on expression stability. Homologous sequences of seven traditional reference genes were also selected as candidates; however, the expression levels of sequences homologous to 18SrRNA and $\beta$-tubulin (TUB) showed distinct differences among treatments, and these two genes were considered unsuitable as reference genes. The remaining five homologous sequences were selected as candidate reference genes. Therefore, there were eight candidate reference genes (Table 1). Four reported traditional reference genes (ChActin for C. heterophylla Fisch. [12], VvUBQ, VvActin for Corylus avellana L. [28] and Cha18S rRNA for C. heterophylla Fisch. $\times$ Corylus avellana L. [29]) in hazelnuts were also selected.

Table 1. Eight candidate reference genes.

\begin{tabular}{|c|c|c|c|c|}
\hline No & Gene ID & Description & Gene & Identity \% \\
\hline 1 & Unigene27057_All & Transcription elongation factor SPT5 & ChaSTP5 & - \\
\hline 2 & Unigene8224_All & Homeodomain-containing transcription factor & ChaTF & - \\
\hline 3 & Unigene376_All & Ubiquitin C & ChaUBC & - \\
\hline 4 & Unigene17976_All & Polyubiquitin 14 (Arabidopsis thaliana, NM_001125450.1a) & ChaUBQ14 & $84.39 \%$ \\
\hline 5 & CL4792.Contig2_All & $\alpha$-tubulin (Betula pendula, FJ228477.1a) & ChaTUA & $90.23 \%$ \\
\hline 6 & CL750.Contig12_All & Actin (Betula pendula, EU588981.1a) & ChaActin & $97.35 \%$ \\
\hline 7 & CL828.Contig4_All & EF1- $\alpha$ (Arabidopsis thaliana, NM_001035916.2a) & ChaEF1- $\alpha$ & $87.90 \%$ \\
\hline 8 & Unigene22682_All & GAPDH (Populus trichocarpa, FN396887.1a) & ChaGAPDH & $91.53 \%$ \\
\hline
\end{tabular}

No. 1-3, new reference genes, selected from transcriptome data. No. 4-8, Sequences homologous to traditional reference genes from the transcriptome data. Species and National Center for Biotechnology Information (NCBI) Accession number of traditional reference gene.

Twelve pairs of primers were generated by software design and literature review (Table 2), and they produced standard curves demonstrating good amplification efficiency (E ranged from $86.3 \%$ to $121.6 \%$ ) and there was a linear relationship (R2 > 0.980) for all tested reference genes, confirming the suitability of the primer pairs for RT-qPCRbased quantification.

Table 2. Primers for candidate reference genes.

\begin{tabular}{ccccc}
\hline Gene & Length (bp) & Efficiencies (E \%) & $\mathbf{R}^{\mathbf{2}}$ & Reference \\
\hline ChaSTP5 & 179 & 109.4 & 0.99 & This study \\
ChaTF & 192 & 91.9 & 0.997 & This study \\
ChaUBC & 155 & 107.1 & 0.986 & This study \\
ChaUBQ14 & 197 & 92.8 & 0.995 & This study \\
ChaTUA & 155 & 97.5 & 0.995 & This study \\
ChaActin & 179 & 91.7 & 0.993 & This study \\
ChaEF1- $\alpha$ & 175 & 86.3 & 0.995 & This study \\
ChaGAPDH & 164 & 88.3 & 0.982 & This study \\
Cha18s rRNA & 277 & 100.8 & 0.988 & [29] \\
ChActin & 101 & 118.1 & 0.984 & {$[30]$} \\
VvUBQ & 99 & 93.2 & 0.997 & {$[28]$} \\
VvActin & 100 & 121.6 & 0.994 & [28] \\
\hline
\end{tabular}

Agarose gel electrophoresis of the products amplified by RT-PCR revealed single fragments in all cases (Figure 1), demonstrating the high specificity of the primers. Amplification of the ChActin gene resulted in a lower molecular weight band, compared with the negative control group, which was found to be a primer dimer. Further, the expression of ChaSTP5 and ChaTF differed among tissues. Accordingly, these preliminary data demonstrate that these two genes were not suitable as reference genes. Using the primer pairs designed for the 12 candidate reference genes, gene-specific amplification was also 
confirmed by the generation of a single peak on melting curve analyses following RT-qPCR (Figure 2).
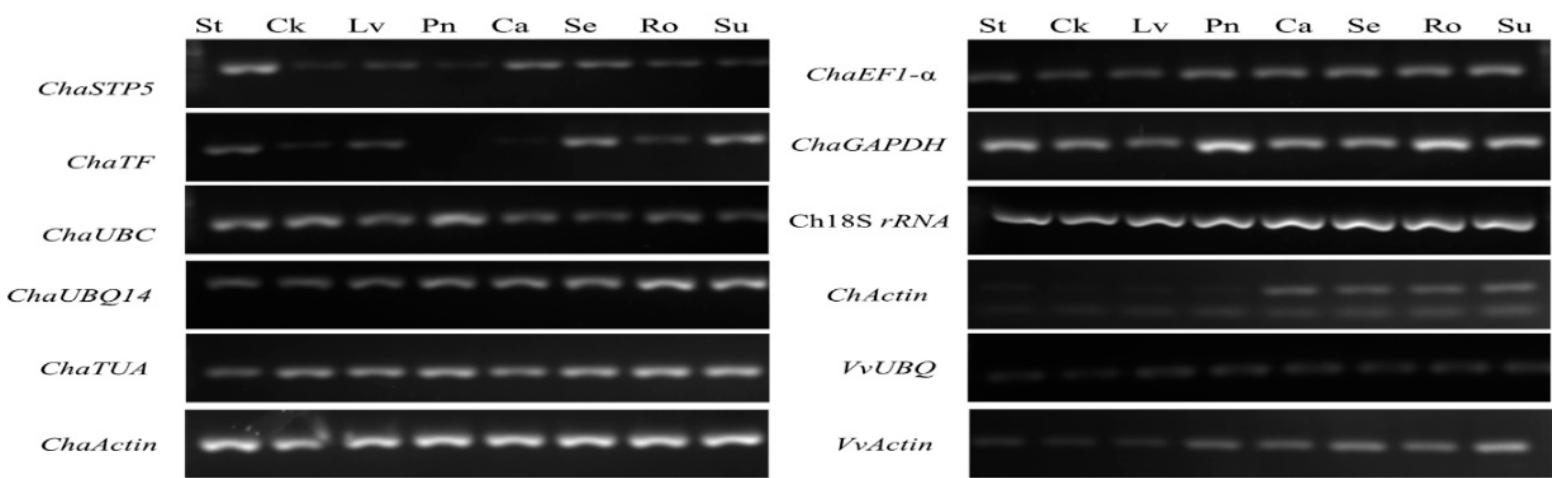

Figure 1. Agarose electrophoresis of 12 candidate reference gene RT-PCR products amplified from different samples. St, blooming styles; Ck, catkins before elongation; Lv, young leaves; Pn, pollen; Ca, cambium of annual branch; Se, green stem; Ro, root tip; Su, sucker.
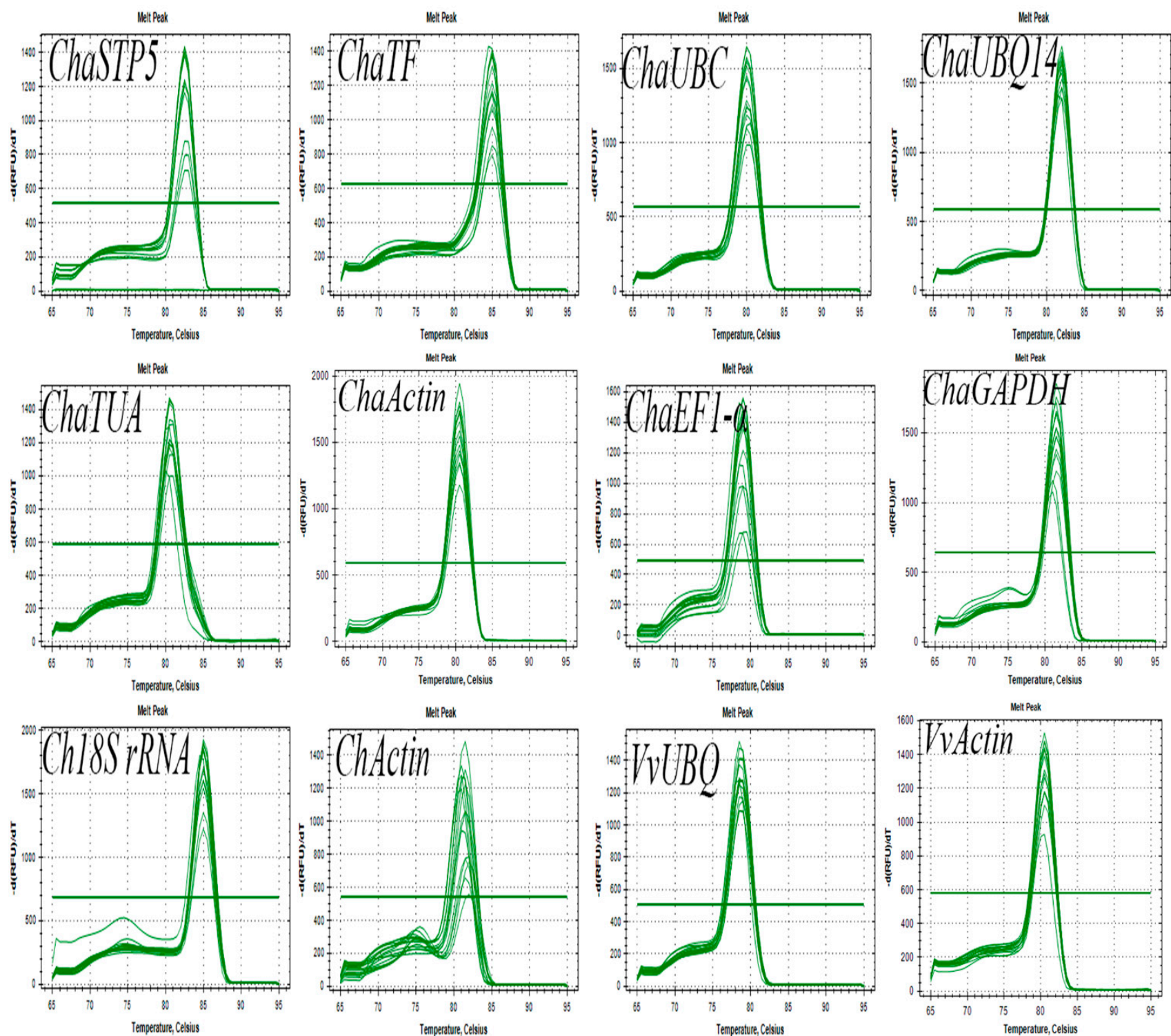

Figure 2. Melt curve analyses of RT-qPCR products for 12 candidate reference genes. 


\subsection{Expression Levels of Selected Candidate Reference Genes}

When assessing a set of reference genes, the most straightforward method is to determine the range of $\mathrm{Cq}$ (quantification cycle) values and calculate the coefficient of variance. From the graph, the $\mathrm{Cq}$ value range for the 12 candidate reference genes in 24 samples was 16.02-32.09 (Figure 3), representing the highest and lowest accumulation levels, respectively, in different tissues, and indicating considerable variation. Cq values are inversely proportional to expression levels, hence the gene with the lowest level of gene expression across all 12 tested samples was ChaSTP5 (Cq range, 24.39-32.09), and that with the highest was Cha18S rRNA (Cq range, 16.02-20.55); the other 10 candidate reference genes exhibited intermediate expression levels.

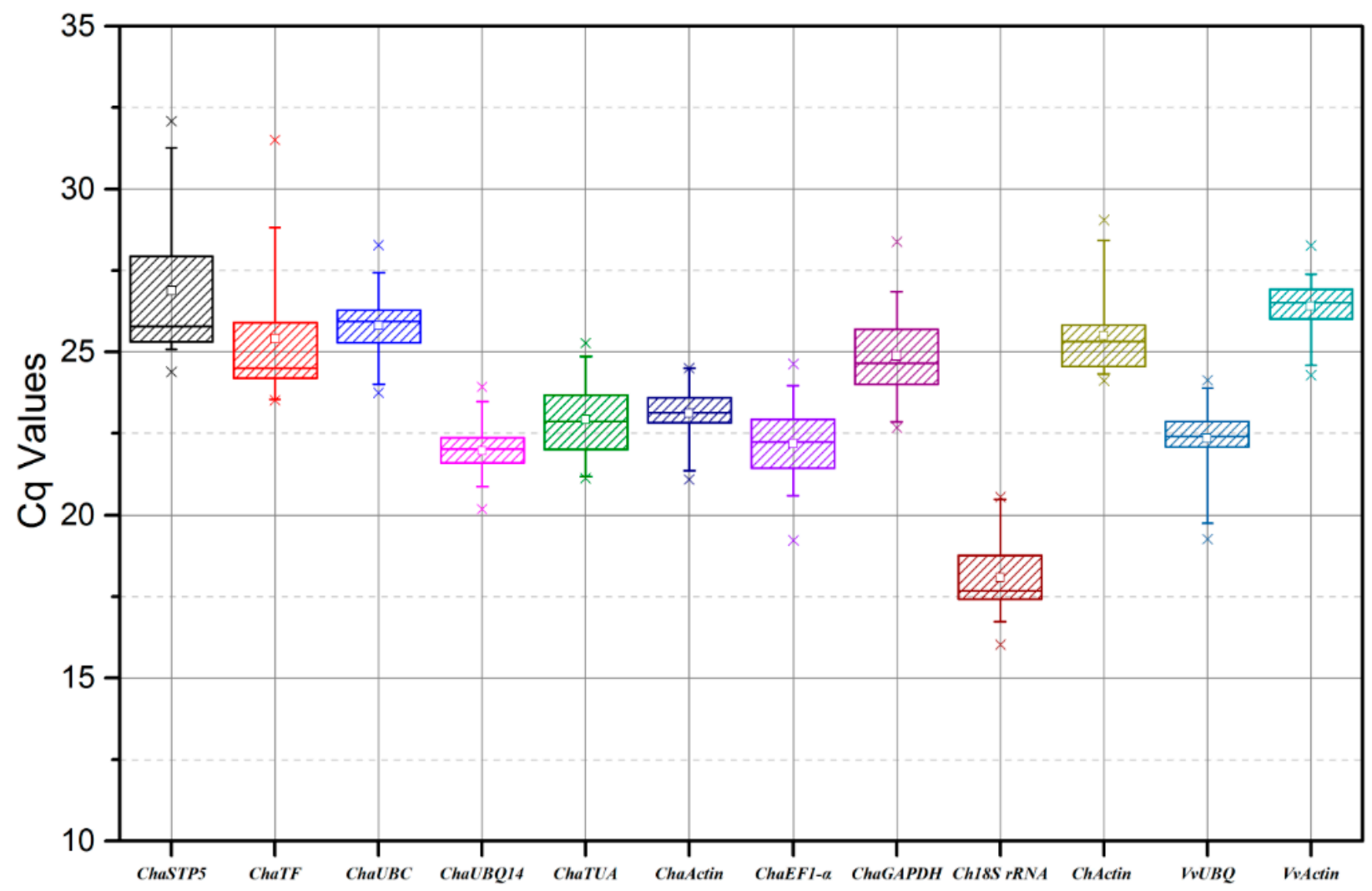

Figure 3. Cq values of candidate reference genes in 24 samples. Boxes indicate the interquartile range. Lines across the boxes depict the medians. Small white boxes within colored boxes indicate mean values. Whiskers represent the 95th and 5th percentiles. The $\times$ symbols denote minimum and maximum values.

The mean Cq value, standard deviation (SD), and coefficient of variation (CV) of each candidate reference gene in all samples was analyzed using Excel (Table 3). According to the coefficient of variation, we made a preliminary assessment of the expression stability of the 12 candidate reference genes. ChaSTP5 $(8.33 \%)$ and ChaTF $(8.05 \%)$ had the worst stability, VvActin (3.34\%) and ChaActin (3.48\%) had the highest stability, and the stability of the remaining candidate reference genes was ordered as follows: ChaUBQ14 >ChaUBQc > VvUBQ $>$ ChActin $>$ ChaTUA $>$ ChaGAPDH $>$ ChaEF1- $\alpha>$ Cha18s-rRNA.

\subsection{Expression Stability of Candidate Reference Genes}

A simple comparison of raw $\mathrm{Ct}$ (threshold cycle) values is insufficient to evaluate the expression stability of candidate reference genes. To minimize bias, a more accurate assessment is required; therefore, we applied four different commonly-used algorithms, geNorm [31], NormFinder [32], BestKeeper [33], and Delta Ct [24], to rank the expression stabilities of the 12 reference genes across all experimental sets. 
Table 3. Statistical analysis of candidate reference gene Cq values.

\begin{tabular}{cccc}
\hline Gene & Mean & SD & CV \\
\hline ChaSTP5 & 26.89 & 2.24 & $8.33 \%$ \\
ChaTF & 25.41 & 2.04 & $8.05 \%$ \\
ChaUBQc & 25.82 & 0.99 & $3.82 \%$ \\
ChaUBQ14 & 21.97 & 0.8 & $3.66 \%$ \\
ChaTUA & 22.93 & 1.17 & $5.10 \%$ \\
ChaActin & 23.13 & 0.8 & $3.48 \%$ \\
ChaEF1- $\alpha$ & 22.19 & 1.22 & $5.50 \%$ \\
ChaGAPDH & 24.87 & 1.33 & $5.36 \%$ \\
Cha18s rRNA & 18.07 & 1.11 & $6.15 \%$ \\
ChActin & 25.5 & 1.26 & $4.94 \%$ \\
VvUBQ & 22.36 & 1.08 & $4.83 \%$ \\
VvActin & 26.4 & 0.88 & $3.34 \%$ \\
\hline
\end{tabular}

\subsection{1. geNorm Analysis}

For relative comparison, geNorm transforms raw $\mathrm{Ct}$ values into quantities, and calculates a gene expression stability measure, $\mathrm{M}$ (where a lower average value of $\mathrm{M}$ indicates more stable expression), for each gene, based on the average pairwise expression ratio between it and each of the other genes under study. The candidate gene is considered unsuitable as a reference gene if it exceeds a threshold of $\mathrm{M}>1.5$, as suggested by geNorm.

In all cases, the $M$ values were $<1$, indicating that the selected genes all had relatively acceptable expression stability values. Nevertheless, it is likely better to choose different reference genes, depending on the samples to be studied. In our study, geNorm selected the best reference genes for each sample group (Figure 4). The two candidate genes, ChaActin and $V v A c t i n$, achieved high expression stability, with $\mathrm{M}<0.7$, in a total of 24 sample groups (Figure 4A), different tissues (Figure 4B), and at different times after pollination (Figure 4C). The $\mathrm{M}$ value was lowest for ChaEF1- $\alpha$ and ChaGAPDH, indicating that they were the most stably expressed gene pair, in styles at $4 \mathrm{~h}$ after cross/self-pollination (Figure $4 \mathrm{D}$ ). When styles at different flowering stages (Figure 4E) were considered, ChaEF1- $\alpha$ and VvActin were the best candidate genes. Finally, ChaActin and Cha18s rRNA were the two most stable genes in male catkins at different stages of elongation (Figure 4F).

The optimal number of reference genes could also be determined using geNorm, according to the pairwise variation value $(\mathrm{Vn} / \mathrm{n}+1)$. The default cut-off threshold of 0.15 was applied, where a $\mathrm{Vn} / \mathrm{Vn}+1$ value $<0.15$ indicates that $\mathrm{n}$ reference genes would be needed for accurate normalization, without introducing another $(n+1)$ reference gene. The V2 $/ 3, \mathrm{~V} 3 / 4$, and V4/5 values for all sample groups (Figure $5 \mathrm{~A}$ ) were $>0.15$, while V5/ 6 was $0.145(<0.15)$, suggesting that five reference genes (ChaActin, VvActin, ChaEF1- $\alpha$, ChaUBQ14, and $V v U B Q$ ) would be adequate for the normalization of our RT-qPCR, and an additional reference gene was not required; however, gene normalization in four sample groups (styles at different times after self-pollination, styles at $4 \mathrm{~h}$ after cross/self-pollination, styles at different flowering stages, and male inflorescence at different elongation stage) (Figure 5C-F) required the use of only two reference genes, since the V2/3 value was $<0.15$. When analyzing different tissues (Figure $5 \mathrm{~B}$ ), $\mathrm{Vn} / \mathrm{Vn}+1$ values were $>0.15$; however, according to the instruction of geNorm ${ }^{\mathrm{TM}}$ housekeeping gene selection kit with perfect Probe $^{\mathrm{TM}}$ (Primerdesign Ltd. Nursling Street, Rownhams, Southampton, SO16 0AJ, United Kingdom), the 0.15 threshold is not a strict restriction. 

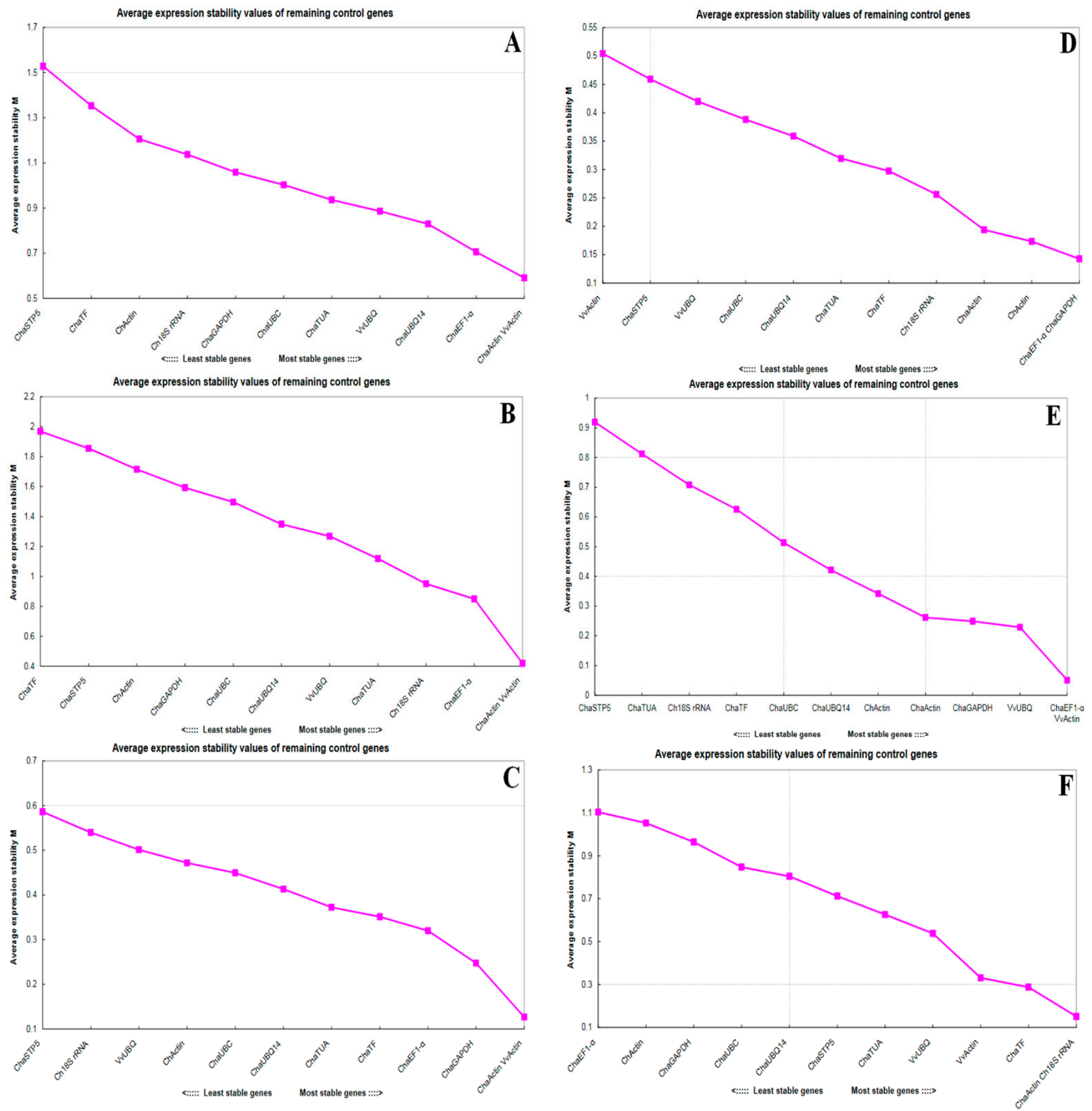

Figure 4. Expression stability $(\mathrm{M})$ of twelve reference genes across different sample groups calculated using geNorm. M values of reference genes (A) in 24 sample groups, (B) in different tissues, (C) at different times after pollination, (D) in styles at $4 \mathrm{~h}$ after cross/self-pollination, (E) at different stages of flowering, and (F) in male catkins at different stages of elongation. 


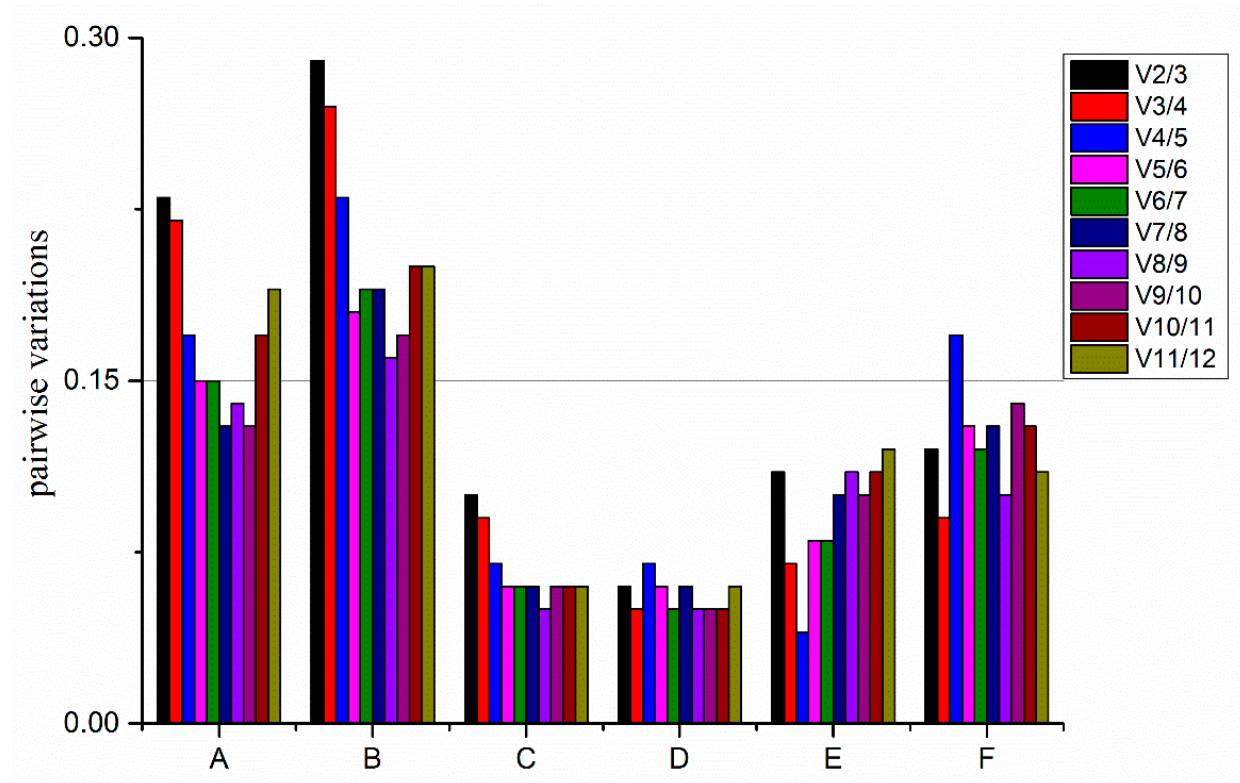

Figure 5. Determination of the optimal number of reference genes for different sample groups using geNorm. (A-F) represent different sample groups. (A) in 24 sample groups, (B) in different tissues, (C) at different times after pollination, (D) in styles at $4 \mathrm{~h}$ aftecross/self-pollination, (E) at different stages of flowering, and (F) in male catkins at different stages of elongation.

\subsubsection{NormFinder Analysis}

The NormFinder program is a Microsoft Excel-based Visual Basic application that determines the expression stabilities of reference genes by ranking all candidate reference genes, based on intra- and intergroup variation for normalization factor calculations, and combining both results into a stability value for each candidate reference gene. This approach avoids misinterpretation caused by artificial selection of co-regulated genes.

We applied NormFinder to calculate stability values (SV), to determine the stability of the candidate reference genes, where SV was lower for more stably expressed genes. Stability values for each gene in the six sample groups are presented in Table 4. ChaActin was the best reference gene in all the sample group (SV = 0.410), as well as the most stably expressed gene in different tissues (SV $=0.357)$, and at different times after selfpollination $(\mathrm{SV}=0.121)$. For the cross- and self-pollination group $(\mathrm{SV}=0.038)$, and the styles group (SV = 0.017), ChaEF1- $\alpha$ had the most stable expression and was the ideal reference gene. Both ChaActin and Cha18s rRNA were good reference genes in male inflorescences $(\mathrm{SV}=0.052)$.

Table 4. Stability values for candidate reference genes generated using NormFinder.

\begin{tabular}{ccccccc}
\hline \multirow{2}{*}{ Gene } & \multicolumn{7}{c}{ Group } \\
\cline { 2 - 7 } & A & B & C & D & E & F \\
\hline ChaSTP5 & 1.546 & 1.663 & 0.510 & 0.398 & 0.968 & 0.671 \\
ChaTF & 1.157 & 1.408 & 0.122 & 0.248 & 0.584 & 0.263 \\
ChaUBC & 0.869 & 1.171 & 0.269 & 0.298 & 0.326 & 0.875 \\
ChaUBQ14 & 0.589 & 0.746 & 0.254 & 0.234 & 0.134 & 0.827 \\
ChaTUA & 0.451 & 0.627 & 0.248 & 0.275 & 0.927 & 0.425 \\
ChaActin & $0.410^{*}$ & $0.357 *$ & $0.121^{*}$ & 0.064 & 0.278 & $0.052^{*}$ \\
ChaEF1- $\alpha$ & 0.461 & 0.539 & 0.270 & $0.038^{*}$ & $0.017^{*}$ & 0.898 \\
ChaGAPDH & 0.838 & 1.205 & 0.248 & 0.057 & 0.405 & 0.743 \\
Cha18s rRNA & 0.557 & 0.697 & 0.396 & 0.246 & 0.665 & $0.052 *$ \\
ChActin & 0.722 & 0.971 & 0.352 & 0.129 & 0.367 & 0.866 \\
VvUBQ & 0.683 & 0.806 & 0.401 & 0.364 & 0.359 & 0.429 \\
VvActin & 0.582 & 0.393 & 0.215 & 0.468 & 0.047 & 0.371 \\
\hline
\end{tabular}

* indicates the most stable candidate reference genes for each sample group. 


\subsubsection{BestKeeper Analysis}

BestKeeper identifies the most stably expressed genes, based on three variables: standard deviation (SD), percentage covariance (CV), and coefficient of correlation (r). In the BestKeeper package, the best reference genes are those that are most stable and have the lowest $\mathrm{CV} \pm \mathrm{SD}(\mathrm{SD}<1)$ and the highest $\mathrm{r}$ [34].

BestKeeper can only analyze ten candidate reference genes simultaneously; therefore, we analyzed all reference genes, except for ChaSTP5 and ChaTF, which had the least stable original $\mathrm{Cq}$ values. The variations (SD and $\mathrm{CV}$ ) in data for all candidate reference genes were subject to preliminary analysis, and the results (Table 5) showed that all tested genes had $S D$ values $<1$ in all samples group, indicating that they were suitable candidate reference genes. $\mathrm{SD}$ values $>1$ were generated for seven candidate reference genes (ChaUBC, ChaTUA, ChaEF1- $\alpha$, ChaGAPDH, Cha18srRNA, ChActin, VvUBQ) in different tissues, one candidate reference gene (ChaTUA) in styles at different stages of flowering, and three candidate reference genes (ChaEF1- $\alpha$, ChaGAPDH, ChActin) in male inflorescences at different stages of elongation, disqualifying them as reference genes. Analysis of Pearson correlation coefficient $(r)$ values showed that the top candidate genes, with $r>0.9$, were as follows: ChaActin was the most stable gene in groups (A, B, C, D, and F), except for group E; while in group E, the order of stability is VvActin, VvUBQ, ChaGAPDH, ChaEF1- $\alpha$, ChaActin, ChaTUA, and ChActin. Although ChaActin was relatively in a lower-ranking, it has a very high $r$ value.

Table 5. Stability analysis of 10 candidate reference genes using BestKeeper.

\begin{tabular}{|c|c|c|c|c|c|c|c|c|c|c|c|}
\hline \multirow{2}{*}{ Group } & \multirow{2}{*}{ Index } & \multicolumn{10}{|c|}{ Gene } \\
\hline & & ChaUBC & ChaUBQ-14 & ChaTUA & ChaActin & ChaEF1- $\alpha$ & ChaGAPDH & Cha18srRNA & ChActin & $V v U B Q$ & VvActin \\
\hline \multirow{3}{*}{ A } & $\mathrm{r}$ & 0.39 & 0.57 & 0.77 & $0.84^{*}$ & $0.91 *$ & 0.59 & 0.47 & 0.57 & 0.58 & 0.77 \\
\hline & SD & 0.73 & 0.59 & 0.91 & 0.56 & 0.91 & 0.99 & 0.87 & 0.90 & 0.69 & 0.65 \\
\hline & CV $(\%)$ & 2.82 & 2.68 & 3.99 & 2.43 & 4.11 & 3.99 & 4.82 & 3.53 & 3.07 & 2.45 \\
\hline \multirow{3}{*}{ B } & $\mathrm{r}$ & 0.32 & 0.44 & 0.76 & $0.92 *$ & $0.91 *$ & 0.44 & 0.74 & 0.56 & 0.69 & 0.85 \\
\hline & SD & 1.20 & 0.83 & 1.47 & 0.82 & 1.48 & 1.46 & 1.11 & 1.64 & 1.13 & 0.86 \\
\hline & CV $(\%)$ & 4.65 & 3.78 & 6.33 & 3.59 & 6.66 & 5.77 & 5.97 & 6.27 & 5.22 & 3.28 \\
\hline \multirow{3}{*}{$\mathrm{C}$} & $\mathrm{r}$ & 0.70 & 0.90 & 0.88 & 0.91 & $0.97^{*}$ & $0.94 *$ & 0.33 & 0.86 & 0.61 & 0.83 \\
\hline & SD & 0.37 & 0.49 & 0.53 & 0.40 & 0.61 & 0.59 & 0.39 & 0.54 & 0.58 & 0.34 \\
\hline & CV $(\%)$ & 1.44 & 2.21 & 2.31 & 1.68 & 2.78 & 2.37 & 2.26 & 2.17 & 2.55 & 1.30 \\
\hline \multirow{3}{*}{$\mathrm{D}$} & $\mathrm{r}$ & -0.02 & 0.35 & 0.92 & $0.96^{*}$ & 0.90 & $0.95 *$ & 0.88 & 0.76 & 0.10 & 0.89 \\
\hline & SD & 0.15 & 0.19 & 0.52 & 0.19 & 0.24 & 0.31 & 0.42 & 0.18 & 0.33 & 0.58 \\
\hline & CV (\%) & 0.59 & 0.87 & 2.31 & 0.81 & 1.08 & 1.26 & 2.36 & 0.70 & 1.47 & 2.16 \\
\hline \multirow{3}{*}{$\mathrm{E}$} & $\mathrm{r}$ & 0.67 & 0.89 & 0.92 & 0.94 & 0.99 & 0.99 & 0.08 & 0.95 & $0.99 *$ & $1.00 *$ \\
\hline & SD & 0.11 & 0.39 & 1.36 & 0.74 & 0.59 & 0.89 & 0.56 & 0.69 & 0.80 & 0.48 \\
\hline & CV $(\%)$ & 0.42 & 1.75 & 6.08 & 3.18 & 2.62 & 3.53 & 3.11 & 2.72 & 3.49 & 1.83 \\
\hline \multirow{3}{*}{ F } & $\mathrm{r}$ & -0.87 & -1.00 & 0.43 & $1.00 *$ & 0.98 & $0.99 *$ & 0.97 & 0.97 & 0.16 & 0.92 \\
\hline & SD & 0.43 & 0.37 & 0.15 & 0.53 & 1.54 & 1.35 & 0.51 & 1.19 & 0.18 & 0.72 \\
\hline & CV (\%) & 1.76 & 1.80 & 0.64 & 2.32 & 6.88 & 5.59 & 2.58 & 4.46 & 0.83 & 2.75 \\
\hline
\end{tabular}

* indicates the most stable candidate reference genes for each sample group.

\subsubsection{Delta Ct Analysis}

The principle of the Delta Ct algorithm is similar to that of geNorm; both are based on Cq values and follow a pairwise approach, but with different procedures and outcomes [35] The progressive exclusion of genes by geNorm increases the tendency to select the most correlated genes, whereas the Delta Ct method compares the relative expression of pairs of genes within each sample, to confidently identify useful reference genes [36].

As shown in Table 6, the results of Delta CT analyses largely agreed with that of geNorm, recommending that the most stable gene in sample groups $\mathrm{A}, \mathrm{B}$, and $\mathrm{C}$ was ChaActin. While VvActin and Cha18s rRNA were the optimal candidate reference genes in sample groups E and F, respectively. In sample group D, ChaActin, ChaEF1- $\alpha$ were the three most stable genes. 
Table 6. Stability value (mean SD) rankings for 12 candidate reference genes according to Delta Ct analysis.

\begin{tabular}{|c|c|c|c|c|c|c|}
\hline \multicolumn{7}{|c|}{ Group } \\
\hline Rank & A & B & C & D & E & $\mathbf{F}$ \\
\hline 1 & $\begin{array}{c}\text { ChaActin } \\
(1.20)\end{array}$ & $\begin{array}{c}\text { ChaActin } \\
(1.43)\end{array}$ & $\begin{array}{c}\text { ChaActin } \\
(0.47)\end{array}$ & $\begin{array}{c}\text { ChaActin } \\
(0.37)\end{array}$ & $\begin{array}{l}\text { VvActin } \\
(0.67)\end{array}$ & $\begin{array}{c}\text { Cha18s rRNA } \\
(0.82)\end{array}$ \\
\hline 2 & $\begin{array}{c}\text { ChaUBC } \\
(1.23)\end{array}$ & $\begin{array}{c}\text { VvActin } \\
(1.48)\end{array}$ & $\begin{array}{l}\text { ChaTF } \\
(0.49)\end{array}$ & $\begin{array}{c}\text { ChaEF1- } \alpha \\
(0.38)\end{array}$ & $\begin{array}{c}\text { ChaEF1- } \alpha \\
(0.68)\end{array}$ & $\begin{array}{c}\text { ChaActin } \\
(0.83)\end{array}$ \\
\hline 3 & $\begin{array}{c}\text { VvActin } \\
(1.27)\end{array}$ & $\begin{array}{c}\text { Cha18s rRNA } \\
(1.67)\end{array}$ & $\begin{array}{l}\text { VvActin } \\
(0.51)\end{array}$ & $\begin{array}{c}\text { ChaGAPDH } \\
(0.38)\end{array}$ & $\begin{array}{c}\text { ChaUBQ14 } \\
(0.74)\end{array}$ & $\begin{array}{c}\text { VvActin } \\
(0.91)\end{array}$ \\
\hline 4 & $\begin{array}{c}\text { ChaEF1- } \alpha \\
(1.32)\end{array}$ & $\begin{array}{c}\text { ChaEF1- } \alpha \\
\text { (1.70) }\end{array}$ & $\begin{array}{c}\text { ChaTUA } \\
(0.56)\end{array}$ & $\begin{array}{l}\text { ChActin } \\
(0.40)\end{array}$ & $\begin{array}{c}\text { ChaActin } \\
(0.78)\end{array}$ & $\begin{array}{c}V v U B Q \\
(0.98)\end{array}$ \\
\hline 5 & $\begin{array}{c}\text { ChaTUA } \\
(1.32)\end{array}$ & $\begin{array}{c}V v U B Q \\
(1.71)\end{array}$ & $\begin{array}{c}\text { ChaUBC } \\
(0.57)\end{array}$ & $\begin{array}{c}\text { ChaUBQ14 } \\
(0.48)\end{array}$ & $\begin{array}{c}\text { ChActin } \\
(0.78)\end{array}$ & $\begin{array}{l}\text { ChaTF } \\
(1.01)\end{array}$ \\
\hline 6 & $\begin{array}{c}\text { ChaUBQ14 } \\
\text { (1.35) }\end{array}$ & $\begin{array}{c}\text { ChaTUA } \\
(1.74)\end{array}$ & $\begin{array}{c}\text { ChaUBQ14 } \\
(0.58)\end{array}$ & $\begin{array}{l}\text { ChaTF } \\
(0.49)\end{array}$ & $\begin{array}{c}\text { ChauBC } \\
(0.79)\end{array}$ & $\begin{array}{c}\text { ChaTUA } \\
(1.02)\end{array}$ \\
\hline 7 & $\begin{array}{c}\text { Cha18s rRNA } \\
(1.40)\end{array}$ & $\begin{array}{c}\text { ChaUBQ14 } \\
\text { (1.87) }\end{array}$ & $\begin{array}{c}\text { ChaGAPDH } \\
(0.58)\end{array}$ & $\begin{array}{c}\text { Cha18s rRNA } \\
(0.49)\end{array}$ & $\begin{array}{c}V v U B Q \\
(0.80)\end{array}$ & $\begin{array}{c}\text { ChaSTP5 } \\
(1.18)\end{array}$ \\
\hline 8 & $\begin{array}{c}\text { ChActin } \\
(1.45)\end{array}$ & $\begin{array}{c}\text { ChActin } \\
(2.01)\end{array}$ & $\begin{array}{c}\text { ChActin } \\
(0.58)\end{array}$ & $\begin{array}{c}\text { ChauBC } \\
(0.51)\end{array}$ & $\begin{array}{c}\text { ChaGAPDH } \\
(0.87)\end{array}$ & $\begin{array}{c}\text { ChActin } \\
(1.22)\end{array}$ \\
\hline 9 & $\begin{array}{c}\text { VvUBQ } \\
(1.48)\end{array}$ & $\begin{array}{c}\text { ChaUBC } \\
(2.17)\end{array}$ & $\begin{array}{c}\text { ChaEF1- } \alpha \\
(0.62)\end{array}$ & $\begin{array}{c}\text { ChaTUA } \\
(0.51)\end{array}$ & $\begin{array}{l}\text { ChaTF } \\
(1.05)\end{array}$ & $\begin{array}{c}\text { ChaUBC } \\
(1.25)\end{array}$ \\
\hline 10 & $\begin{array}{c}\text { ChaGAPDH } \\
\text { (1.65) }\end{array}$ & $\begin{array}{c}\text { ChaSTP5 } \\
(2.32)\end{array}$ & $\begin{array}{c}\text { Cha18s rRNA } \\
(0.69)\end{array}$ & $\begin{array}{c}V v U B Q \\
(0.61)\end{array}$ & $\begin{array}{c}\text { Cha18s rRNA } \\
(1.14)\end{array}$ & $\begin{array}{c}\text { ChaGAPDH } \\
\text { (1.33) }\end{array}$ \\
\hline 11 & $\begin{array}{l}\text { ChaTF } \\
(2.04)\end{array}$ & $\begin{array}{c}\text { ChaGAPDH } \\
(2.40)\end{array}$ & $\begin{array}{c}V v U B Q \\
(0.71)\end{array}$ & $\begin{array}{c}\text { VvActin } \\
(0.62)\end{array}$ & $\begin{array}{c}\text { ChaTUA } \\
(1.40)\end{array}$ & $\begin{array}{c}\text { ChaUBQ14 } \\
\text { (1.34) }\end{array}$ \\
\hline 12 & $\begin{array}{c}\text { ChasTP5 } \\
(2.29)\end{array}$ & $\begin{array}{l}\text { ChaTF } \\
(2.72)\end{array}$ & $\begin{array}{c}\text { ChaSTP5 } \\
(0.81)\end{array}$ & $\begin{array}{c}\text { ChaSTP5 } \\
(0.65)\end{array}$ & $\begin{array}{c}\text { ChasTP5 } \\
(1.43)\end{array}$ & $\begin{array}{c}\text { ChaEF1- } \alpha \\
\text { (1.55) }\end{array}$ \\
\hline
\end{tabular}

2.3.5. Comprehensive Evaluation of the Stability of Candidate Reference Genes in 24 Samples

To determine the optimal reference genes, The RefFinder approach (https:/ / www. heartcure.com.au/reffinder/) was used to determine the comprehensive rankings of candidate reference genes based on the results of four common analysis programs (geNorm, NormFinder, BestKeeper, and Delta Ct) [37]. The comprehensive ranking of RefFinder was shown in Table 7, ChaActin and VvActin were selected as the most suitable reference genes. At the same time, the most suitable reference gene for each group of samples selected from different software packages as shown in Table 8. ChaActin and ChaEF1- $\alpha$ were most stable in different times after self-pollination (Sample group C) and $4 \mathrm{~h}$ after self- and cross-pollination (sample group D), respectively. Both of them were considered as the most suitable reference genes for pollen-pistil interaction in Corylus.

Table 7. Stability rankings of 12 candidate reference genes in all samples.

\begin{tabular}{cccccc}
\hline Gene & Ranking Order & Gene & Ranking Order & Gene & Ranking Order \\
\hline ChaActin & 1 & ChaTUA & 5 & ChActin & 9 \\
VvActin & 2 & VvUBQ & 6 & ChaGAPDH & 10 \\
ChaUBQ14 & 3 & Ch18S rRNA & 7 & ChaTF & 11 \\
ChaEF1- $\alpha$ & 4 & ChaUBC & 8 & ChaSTP5 & 12 \\
\hline
\end{tabular}

\subsection{Validation of Selected Candidate Reference Genes}

To further evaluate the reliability of the top two reference genes (ChaActin and ChaEF1- $\alpha$ ), we selected CavPrx (Corylus avellana peroxidase) as a target gene for RT-qPCR amplification to validate the normalization efficiency of the selected reference genes. 
Table 8. The most suitable reference gene for each group of samples selected from different software packages.

\begin{tabular}{clccc}
\hline Samples/Algorithms & geNorm & NormFinder & BestKeeper & Delta Ct \\
\hline A & ChaActin & ChaActin & ChaActin & ChaActin \\
B & ChaActin & ChaActin & ChaActin & ChaActin \\
C & ChaActin & ChaActin & ChaActin & ChaActin \\
D & ChaEF1- $\alpha$ & ChaEF1- $\alpha$ & ChaActin & ChaActin \\
E & ChaEF1- $\alpha$ & ChaEF1- $\alpha$ & ChaActin & VvActin \\
F & ChaActin & ChaActin & ChaActin & Cha18s rRNA \\
\hline
\end{tabular}

Our result showed that the CavPrx expression in mature styles was three-fold more abundant than that in immature styles and almost absent in leaves and three different developmental stages of catkin (Figure 6A). Moreover, we also found out that the expression level of CavPrx in two compatible pollinations at $4 \mathrm{~h}$ was higher than in two incompatible pollinations at $4 \mathrm{~h}$ (Figure 6C). Our results are consistent with the findings reported by Beltramo et al. After self-pollination (Figure 6B), the expression level of CavPrx showed an upward-downward-upward trend, reaching a maximum value at $2 \mathrm{~h}$. In summary, ChaActin and ChaEF1- $\alpha$ are suitable reference gene to analyze the expression of related genes involved in pollen-pistil interaction.

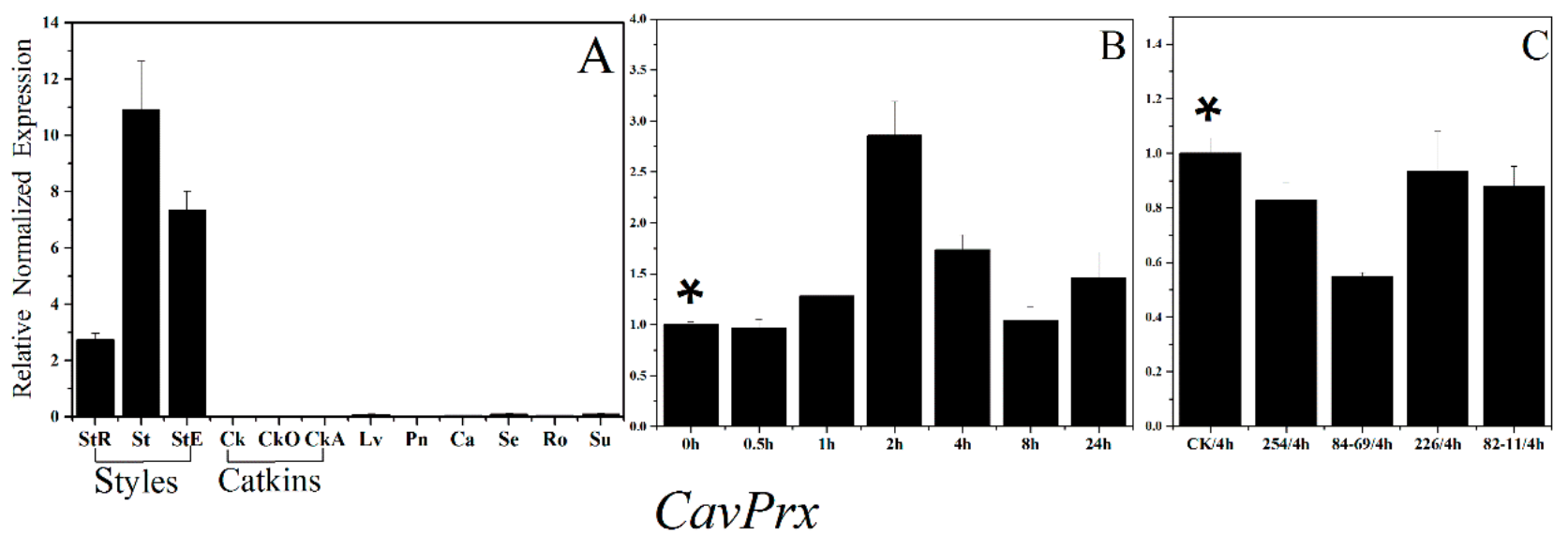

Figure 6. Expression analysis of the target gene, CavPrx, using ChaActin and ChaEF1- $\alpha$ as reference genes. ${ }^{*}$ Control samples. The expression level of CavPrx (A) in different tissues, (B) at different times after self-incompatible pollination, (C) at $4 \mathrm{~h}$ after different affinity pollination. StR, styles at red-dot stage; St, blooming styles; StE, styles at the end-flower stage; Ck, catkins before elongation; $\mathrm{CkO}$, catkins during elongation; $\mathrm{CkA}$, catkins after elongation; Lv, young leaves; $\mathrm{Pn}$, pollen; $\mathrm{Ca}$, cambium of annual branch; Se, green stem; Ro, root tip; Su, sucker; $0 \mathrm{~h}$, self-pollination $0 \mathrm{~h}$; $0.5 \mathrm{~h}$, self-pollination $0.5 \mathrm{~h}$; $1 \mathrm{~h}$, self-pollination $1 \mathrm{~h} ; 2 \mathrm{~h}$, self-pollination $2 \mathrm{~h} ; 4 \mathrm{~h}$, self-pollination $4 \mathrm{~h} ; 8 \mathrm{~h}$, self-pollination $8 \mathrm{~h} ; 24 \mathrm{~h}$, self-pollination 24 h; $\mathrm{CK} / 4 \mathrm{~h}$, non-pollination $4 \mathrm{~h}$; 254/4 h: incompatible pollination $4 \mathrm{~h}$ with 84-254; 84-69/4 h; incompatible pollination $4 \mathrm{~h}$ with $84-69 ; 226 / 4 \mathrm{~h}$, compatible pollination $4 \mathrm{~h}$ with $84-226$; 82-11/4 h, compatible pollination $4 \mathrm{~h}$ with $82-11$.

\section{Discussion}

RT-qPCR is an established method for gene expression analysis because of its high sensitivity, specificity, and reproducibility [38,39]; however, the bias caused by the RNA extraction, cDNA reverse transcription, and RT-qPCR processes can easily influence the final results of RT-qPCR [40]. To obtain more reliable experimental results, it is essential to introduce one or more reference genes for normalization [41]. According to previous research, an ideal reference gene should be stably expressed in all tissues, developmental stages, and physiological conditions, and may differ from the reference genes are suggested for use under other conditions [42]. Improper use of reference genes may lead to difficulties in detecting minor differences in gene expression or even erroneous or contrary conclusions [43]. Therefore, the most suitable reference genes, that show constant expression profiles, should be selected for specific experimental conditions and materials [44]. 
The geNorm, NormFinder, Delta Ct, BestKeeper, and RefFinder methods are commonlyused to evaluate the stability of reference gene expression, and none is currently considered superior to the others. Some reports have suggested that applying different analysis software can result in different validation results in the same tissue or treatment, due to their distinct statistical algorithms and analytical procedures [18]. To guarantee a comprehensive comparison, candidate reference genes included in this research containing traditional reference genes and reference genes obtained by analysis of transcriptome data. Five different statistical approaches, geNorm, NormFinder, Delta Ct, BestKeeper, and RefFinder were used to evaluate the expression stability of the 12 candidate reference genes.

The BestKeeper method offers an apparent solution to measurement of stability, since it uses standard deviation as a direct measure of variation; however, this means that the only condition applied is that the genes under evaluation are not co-regulated. In this case, a gene could show a low standard deviation while still being a good reference gene. Nevertheless, it is risky to assume that genes are not co-regulated, as this cannot be easily demonstrated. The geNorm and the comparative Delta $\mathrm{Ct}$ approaches rank genes mainly according to their correlation; these methods tackle the same problem; that is, they select the most stable genes by assuming "that the control reference genes are not co-regulated". Consequently, selection of two co-regulated genes could ruin the analysis, leading to selection of unsuitable reference genes [31]. Finally, NormFinder takes into account intergroup variation, which should be as low as possible for a good reference gene; hence, it is not affected by the drawbacks of analysis of gene co-regulation. Therefore, the advantages and disadvantages of each algorithm should be considered when analyzing presumed reference genes, according to the experimental scheme. NormFinder and geNorm are the most extensive methodologies for finding optimum reference genes. In most cases, NormFinder and geNorm generate very similar results and this was confirmed in our experiments; the selection of optimal reference genes in all sample groups using NormFinder was in good agreement with those selected using geNorm.

The aim of our study was to select the suitable reference genes for self-incompatibility response in Corylus. We performed a combined ranking of the 12 candidate reference genes in all samples, based on the RefFinder. ChaActin, VvActin, ChaUBQ14, and ChaEF1- $\alpha$ were selected as suitable reference genes. Then we analyzed the most suitable reference gene for each group of samples using four different software packages. As shown in Table 8, we found that ChaActin was the most suitable reference gene in most sample groups (A, B, C and F), ChaEF1- $\alpha$ exhibits excellent stability in sample group $\mathrm{D}$ and $\mathrm{E}$ by geNorm and NormFinder. Moreover materials from sample group $\mathrm{C}$ and $\mathrm{E}$ are involved in pollen-pistil interaction. Therefore, we selected ChaActin and ChaEF1- $\alpha$ as appropriate reference genes from our study, which could be used for the subsequent analysis of the expression of self-incompatibility (SI)-related genes.

In Corylus, previous research by Beltramo et al. demonstrated that CavPrx expression levels in mature styles were threefold those in immature styles, while it was almost absent in leaves and catkins. Moreover, the expression was higher (by almost 25\%) in styles pollinated with compatible pollen than in incompatible pollinated styles [28]. In analysis of reference gene validation, we found the similar expression trend with Beltramo's study is that the CavPrx expression of compatible pollinations was higher than that of incompatible pollinations. However the numerical value of increased expression of CavPrx was different from that in Beltramo's study. We think this difference is due to the different pollinators. This regulation pattern could be noticed also for stigma-specific peroxidase (SSP) of Senecio squalidus, which expression was detected exclusively in the stigmas and increased with flower development, reaching a maximum level in mature stigmas [45]. This expression level of peroxidase gene suggests a possible involvement in pollen-pistil interaction; however, its possible function(s) remains to be further discussed.

Actin is also often used as a reference gene in plant species; for example, Actin was considered as a suitable reference gene for analyzing mRNA expression levels in different organs and at different development periods in Lycoris sprengeri comes ex Baker flowers 
and different Lycoris radiata (L'Her.) Herb. hybrids bulbs [46]. Wang et al. showed that Actin was the best reference gene for analysis of target gene expression levels in carrot (Daucus carota) roots and leaves at all five developmental stages [47]. Further, Fang et al. suggested that Actin was a suitable reference gene for RT-qPCR in plants infected with Rice Stripe Virus (RSV) and Rice Black Streaked Dwarf Virus (RBSDV) [48]. In addition, $E F 1-\alpha$ is often used as reference gene. Zhang et al. used EF1- $\alpha / 18 S$ rRNA as reference gene to analyze the levels of farnesyl pyrophosphate synthetase (FPS) gene transcription in Dendrobium officinale [49]. Further, Li et al. evaluated the expression stability of eight candidate reference genes in different organs, during developmental stages, and under seven treatments in Achyranthes bidentata BI., and EF1- $\alpha$ was verified as a suitable reference gene across all tested samples [50]. However, previously published researches have stated that the ideal stable reference genes do not exist and the stability of these reference genes or a certain reference gene varied among various plant species and even changed under different experimental treatments in same species [19]. Chen have proved that ChActin (Actin from C. heterophylla Fisch.) was suitable as a reference gene for semi-quantitative PCR of hazelnut in different organs (bark, flower buds, catkins, and seed) [30]. However, in our study, the stability of ChaActin was superior to that of ChActin, because ChActin was not expressed in some particular tissue (blooming styles, catkins before elongation, leaves, and pollen) that involved in our experimental materials. Meanwhile, this result also indicated that reference genes obtained from primers designed based on sequences of experimental materials were more stable and the acquisition of related sequences from research materials can accelerate reference gene screening.

As the principles underlying the four programs used in this study were not the same, the stability rankings of the 12 candidate reference genes generated differed among them, indicating that the four programs should be used for simultaneous analysis when choosing reference genes, to provide more reliable screening results. Growing evidence suggests that the selection of more than one reference gene can provide more accurate data in plant RT-qPCR analysis [51]. Our results suggest that the optimal reference genes vary among samples. Therefore, selecting a suitable combination of reference genes, according to the experimental conditions and materials used, is necessary.

Except for the using of traditional reference genes and their homologue-sequences, it is also important to screen suitable reference genes from transcriptome database. To date, many researchers used gene expression databases, such as transcriptome data, to rapidly and efficiently screen for stable reference genes. For example, UBC9 and TUB were identified as the most appropriate reference genes for RT-qPCR normalization in a hyper accumulating ecotype of Sedum alfredii, based on transcriptome data [52]. Zhu et al. selected $A C T B$ and $U B C E$ as reference genes during abscisic acid (ABA) treatment and dormancy transition, based on Chinese cherry flower bud transcriptome data [53]. Liu et al. assessed 22 candidate reference of tree peony including 16 new reference genes form transcriptome data and six traditional reference genes. Four newly reference genes (PUF1639, MBF1A, PP2CFP and RPS9) were selected and were superior to traditional ones in terms of their expression stability [54].

\section{Materials and Methods}

\subsection{Plant Materials and Pollination Treatments}

In this study, the Ping'ou hybrid hazelnut "Dawei" (breeding code name: 84-254), "Liaozhen No. 3" (breeding code name: 84-226), "Liaozhen No. 7" (breeding code name: 82-11), and "Liaozhen No. 9" (breeding code name: 84-69) cultivars were used as samples. Trees were grown in Yuquanshan hazelnut experimental field at the Chinese Academy of Forestry.

An appropriate amount of one-year-old branches (approximately $60-80 \mathrm{~cm}$ long) were collected from all cultivars grown in the field in early spring, 2017, before the red dot stage of the stigmatic style (there are no complete flowers in hazelnuts; a cluster of red stigmatic styles extrudes from the tips of female flowers during anthesis), based on the 
phenological period. "Dawei" branches were emasculated, cleaned, and stored in a cold storage at $0{ }^{\circ} \mathrm{C}-2{ }^{\circ} \mathrm{C}$ for subsequent style collection and pollination. Branches from "Dawei", "Liaozhen No. 3", "Liaozhen No. 7", and "Liaozhen No. 9", with abundant well-developed male inflorescences were collected, cleaned and water-cultured in the greenhouse at $25^{\circ} \mathrm{C}$, with segregation. After the catkins elongated and pollen shed, pollen was collected directly from the catkins and stored in cotton-stoppered vials in a $-80{ }^{\circ} \mathrm{C}$ freezer. As well as "Dawei" branches, catkins samples were also collected before elongation, at the beginning of elongation, and after elongation, for the experiment.

Based on the results of a previous experiment, 30 stigmatic styles per sample were required for RNA extraction. Emasculated "Dawei" branches were removed from cold storage and randomly grouped into twelve groups ( $>15$ branches per group) and then water-cultured in greenhouses at $25{ }^{\circ} \mathrm{C}$ (humidity, $60 \%$ ). One group of branches was used for sampling styles at different stages of blooming. When the female flowers were at the full blooming stage, styles from seven groups of branches were pollinated with the pollen of "Dawei" and collected 0, 0.5, 1, 2, 4, 8, and $24 \mathrm{~h}$ after pollination; the styles from another three groups of branches were pollinated with pollen from "Liaozhen No. 3", "Liaozhen No. 7", and "Liaozhen No. 9" and collected $4 \mathrm{~h}$ after pollination. The styles from the last group were treated as controls and collected after $4 \mathrm{~h}$, mature styles were dissected from the female flowers, immediately immersed in liquid nitrogen, and stored at $-80^{\circ} \mathrm{C}$.

The samples of different tissues listed in Table 9 were collected in the late spring of 2017. The cambium of annual branches and root suckers were sampled in the field, while the young leaves, green stems, and root tips were sampled from the tissue cultured saplings.

Table 9. Description of samples.

\begin{tabular}{|c|c|c|c|c|c|c|}
\hline & Group & Sample & Description & Group & Sample & Description \\
\hline \multirow{14}{*}{ A } & B & St & Blooming styles & \multirow{14}{*}{ A } & $0 \mathrm{~h}$ & Styles, $0 \mathrm{~h}$ after self-pollination \\
\hline & & $\mathrm{Ck}$ & Catkins before elongation & & $0.5 \mathrm{~h}$ & Styles, $30 \mathrm{~m}$ after self-pollination \\
\hline & & $\mathrm{Lv}$ & Young leaves & & $1 \mathrm{~h}$ & Styles, $1 \mathrm{~h}$ after self-pollination \\
\hline & & Pn & Pollen & & $2 \mathrm{~h}$ & Styles, $2 \mathrm{~h}$ after self-pollination \\
\hline & & $\mathrm{Ca}$ & Cambium of annual branch & & $4 \mathrm{~h}$ & Styles, $4 \mathrm{~h}$ after self-pollination \\
\hline & & Se & Green stem & & $8 \mathrm{~h}$ & Styles, $8 \mathrm{~h}$ after self-pollination \\
\hline & & Ro & Root tip & & $24 \mathrm{~h}$ & Styles, $24 \mathrm{~h}$ after self-pollination \\
\hline & & $\mathrm{Su}$ & Root Sucker & & $\mathrm{CK} / 4 \mathrm{~h}$ & Styles, $4 \mathrm{~h}$ without pollination \\
\hline & \multirow[t]{3}{*}{$\mathrm{E}$} & StR & Styles at red-dot stage & & "Dawei"/4 h & Styles, $4 \mathrm{~h}$ after incompatible pollination with "Dawei" \\
\hline & & St & Blooming styles & & "Liaozhen No. 9"/4 h & $\begin{array}{l}\text { Styles, } 4 \mathrm{~h} \text { after incompatible pollination with } \\
\text { "Liaozhen No.9" }\end{array}$ \\
\hline & & StE & Styles at end-flower stage & & "Liaozhen No. 3" /4 h & $\begin{array}{l}\text { Styles, } 4 \text { h after compatible pollination with "Liaozhen } \\
\text { No.3" }\end{array}$ \\
\hline & \multirow[t]{3}{*}{$\mathrm{F}$} & $\mathrm{Ck}$ & Catkins before elongation & & "Liaozhen No. 7"/4 h & $\begin{array}{l}\text { Styles, } 4 \text { h after compatible pollination with "Liaozhen } \\
\text { No.7" }\end{array}$ \\
\hline & & $\mathrm{Ck} 0$ & $\begin{array}{c}\text { Catkins at the beginning of the } \\
\text { elongation }\end{array}$ & & & \\
\hline & & CkA & Catkins after elongation & & & \\
\hline
\end{tabular}

A total of 24 samples (A) were collected in this study, including different tissues (B), "Dawei" styles at different times after self-pollination (C); different styles at $4 \mathrm{~h}$ after cross/self-pollination (D); styles at different flowering stages (E); and male catkins at different elongation stages (F) (Table 9). After collection, all samples were immediately immersed in liquid nitrogen and stored at $-80^{\circ} \mathrm{C}$ for subsequent RNA extraction.

\subsection{Candidate Reference Gene Selection and Primer Design}

In our previous study, a set of style transcriptome data were obtained during compatible/incompatible pollen-stigma interactions of the Ping'ou hybrid hazelnut "Dawei" (unpublished data). Using this transcriptome data, new candidate reference genes were screened based on False Discovery Rate (FDR) and Log2 ratio of gene expression values; threshold used were FDR $<0.01$ and $\log 2$ ratio between -1 and 1 . Using the same screening criteria that selected for new candidate reference genes, homologous sequences of seven traditional reference genes, including Actin, Ubiquitin, $18 \mathrm{~S}$ ribosomal RNA, alpha tubulin, beta-tubulin, elongation factor 1-alpha, and GAPDH, were selected from the transcriptome data. These sequences were listed in the supplementary material. Further, some published 
reference genes (ChActin [12], VvUBQ, VvActin [28], and Cha18S rRNA [29]) of hazelnuts were also used as the candidates genes for evaluation in this study.

RT-qPCR primers were designed for all genes using the Primer 3 program (http:// bioinfo.ut.ee/primer3-0.4.0/). To ensure maximum specificity and efficiency during PCR amplification, a stringent set of criteria were applied for primer design $[55,56]$, including optimal melting temperatures $(\mathrm{Tm})$ of $58{ }^{\circ} \mathrm{C}-62{ }^{\circ} \mathrm{C}$, lengths of $19-21$ nucleotides, guanine and cytosine (GC) content of $45 \%-55 \%$, and PCR amplicon lengths of 150-200 bp. These primers were analyzed for specificity using the NCBI Basic Local Alignment Search Tool (BLAST) program (http://www.ncbi.nlm.nih.gov/BLAST/). All primer sequences are presented in Table 10 and were synthesized by Beijing Liuhe Huada Gene Technology Co., Ltd.

Table 10. RT-qPCR primer sequences.

\begin{tabular}{|c|c|c|}
\hline Gene & Primer $\left(5^{\prime}-3^{\prime}\right)$ & Temperature $\left({ }^{\circ} \mathrm{C}\right)$ \\
\hline \multirow{2}{*}{ ChaSTP5 } & F: ACCATTTCCGGATGTTTGAG & \multirow[b]{2}{*}{58} \\
\hline & R: GTCGCCCTTCTTACAGTTGC & \\
\hline \multirow{2}{*}{ ChaTF } & F: GTGCCTAGCCATCCTCATGT & \multirow[b]{2}{*}{60} \\
\hline & R: ATCACCCTGACATCCTCGTC & \\
\hline \multirow[b]{2}{*}{ ChaUBC } & F: CAGGCTCGCCAATCTTACTC & \multirow[b]{2}{*}{54} \\
\hline & R: ACССССTTTTTCAGAAGCAT & \\
\hline \multirow{2}{*}{ ChaUBQ14 } & F: CCTTGCATCTGGTGTTGAGA & \multirow{2}{*}{60} \\
\hline & R: AGTACGCCCATCCTCCAAT & \\
\hline \multirow{2}{*}{ ChaTUA } & F: TCTCCACAGGTTTCCACCTC & \multirow[b]{2}{*}{60} \\
\hline & R: GTGTAGGTGGGTCGCTCAAT & \\
\hline \multirow{2}{*}{ ChaActin } & F: GAGCTGAGAGATTCCGTTGC & \multirow{2}{*}{56} \\
\hline & R: AGCAATACCTGGGAACATGG & \\
\hline \multirow{2}{*}{ ChaEF1- $\alpha$} & F: TTGCCTTTACCCTTGGTGTC & \multirow{2}{*}{54} \\
\hline & R: TCGAAACCAGAGATGGGAAC & \\
\hline \multirow{2}{*}{ ChaGAPDH } & F: AGCTCGTCGCTGTTAACGAT & \multirow{2}{*}{60} \\
\hline & R: GTTCCTGAAGCCGAAAACTG & \\
\hline \multirow{2}{*}{ Cha18s rRNA } & F: AGACACTCGTGCCTTCTTGCC & \multirow{2}{*}{60} \\
\hline & R: CAACGATGCGTGACACCCAG & \\
\hline \multirow{2}{*}{ ChActin } & F: TGGTCAAGGCTGGGTTTGC & \multirow{2}{*}{58} \\
\hline & R: CTGACCCATCCCAACCATGA & \\
\hline \multirow{2}{*}{$V v U B Q$} & F: TCTGAGGCTTCGTGGTGGTA & \multirow{2}{*}{60} \\
\hline & R: AGGCGTGCATAACATTTGCG & \\
\hline \multirow{2}{*}{ VvActin } & F: GCCCCTCGTCTGTGACAATG & \multirow{2}{*}{56} \\
\hline & R: CCTTGGCCGACCCACAATA & \\
\hline \multirow{2}{*}{ CavPrx } & F: CTCGAGGGTTTGACGTTGTTG & \multirow{2}{*}{60} \\
\hline & R: GCTTCAGCAGCAAGGGCTAGA & \\
\hline
\end{tabular}

\subsection{Total RNA Extraction and $c D N A$ Synthesis}

Total RNA was extracted from samples using the cetyltrimethylammonium bromide (CTAB) method [57]. RNA integrity was evaluated by electrophoresis in $1 \%$ agarose gel and staining with GelRed Nucleic Acid Gel Stain 10,000 $\times$ in water (Biotium, Fremont, CA, USA). A NanoDrop 8000 spectrophotometer (Thermo, Wilmington, DE, USA) was then used to determine the purity and concentration of the RNA samples. Total RNA samples $(1 \mu \mathrm{g})$ were reverse transcribed to generate cDNA using an iScript ${ }^{\mathrm{TM}} \mathrm{CDNA}$ synthesis kit (Bio Rad, Hercules, CA, USA) in a total volume of $20 \mu \mathrm{L}$, according to the manufacturer's protocol. cDNA preparations were diluted 5-fold with nuclease-free deionized water (Tiangen, Beijing, China) for use as template in PCR analysis.

\subsection{RT-PCR and RT-qPCR Analysis}

RT-PCR was performed in $25 \mu \mathrm{L}$, containing $12.5 \mu \mathrm{L} 2 \times$ TSINGKE Master Mix (TSINGKE, Beijing, China), $1 \mu \mathrm{L}$ of each primer $\mathrm{F}(10 \mu \mathrm{M})$ and $\mathrm{R}(10 \mu \mathrm{M}), 1 \mu \mathrm{L}$ of cDNA, and $9.5 \mu \mathrm{L}$ of PCR-grade water, in a Veriti 96-well thermal cycler (Applied Biosystems, Foster City, CA, USA), with the following steps: $94^{\circ} \mathrm{C}$ for $3 \mathrm{~min} ; 35$ cycles of $94^{\circ} \mathrm{C}$ for $30 \mathrm{~s}$, Tm for $45 \mathrm{~s}, 72{ }^{\circ} \mathrm{C}$ for $30 \mathrm{~s}$; then $72{ }^{\circ} \mathrm{C}$ for $10 \mathrm{~min}$ and maintained at $4{ }^{\circ} \mathrm{C}$. PCR products were separated by $1.5 \%$ agarose gel electrophoresis and visualized with GelRed Nucleic Acid Gel Stain 10,000× in water (Biotium, USA). 
RT-qPCR amplification was performed using a CFX 96TM Real-Time system (Bio Rad, USA), with iTaq ${ }^{\text {TM }}$ Universal SYBR ${ }^{\circledR}$ Green Supermix (Bio Rad, USA). Each PCR reaction was performed in a $20 \mu \mathrm{L}$ volume, containing: $4 \mu \mathrm{L}$ cDNA, $10 \mu \mathrm{L}$ iTaq Universal SYBR Green Supermix $(2 \times), 0.5 \mu \mathrm{L}$ of each $10 \mu \mathrm{M}$ Primer F and R, and $5 \mu \mathrm{L}$ PCR-grade water. Thermal cycler parameters were as follow: $3 \mathrm{~min}$ at $95^{\circ} \mathrm{C}$; then 40 cycles of $5 \mathrm{~s}$ at $94{ }^{\circ} \mathrm{C}$, $30 \mathrm{~s}$ at $56^{\circ} \mathrm{C}$. Melting curve analysis was carried out from $65{ }^{\circ} \mathrm{C}$ to $95^{\circ} \mathrm{C}$ to evaluate the specificity of the PCR products. Cq (quantification cycle) values were automatically determined and each PCR reaction was repeated three times (technical replicates) per sample. No-template controls were included. The PCR programming comprised an initial denaturation at $95{ }^{\circ} \mathrm{C}$ for $30 \mathrm{~s}$, followed by 40 cycles of denaturation at $95{ }^{\circ} \mathrm{C}$ for $3 \mathrm{~s}$ and primer annealing and extension at $56^{\circ} \mathrm{C}$ for $30 \mathrm{~s}$, with fluorescent signal recording. Subsequently, a melting curve analysis was carried out from $65^{\circ} \mathrm{C}$ to $95^{\circ} \mathrm{C}$ to evaluate the specificity of the PCR products. Five serially diluted cDNA samples were used as template to construct standard curves for each primer pair, where RT-qPCR composition and conditions were as described above. Standard curves were constructed by linear regression, based on Cq values for all dilution points in a series, using CFX Manager 3.1 software (Bio Rad, Hercules, CA, USA). Correlation coefficient (R2) and slope values were obtained from the standard curve, and corresponding PCR amplification efficiencies (E) calculated, according to the following equation: $\mathrm{E}=10(-1 /$ slope $)$.

\subsection{Data Analysis}

Statistical analysis of Cq values was conducted using Microsoft Excel 2010. Ct values were transformed into relative quantities ( $Q$ values) using qBase $[16,58,59]$ with the following formula:

$$
\mathrm{Q}=\mathrm{E} \text { Cq } \min -\mathrm{Cq} \text { sample }
$$

where ' $E$ ' indicates the PCR amplification efficiency, Cq min the minimum Cq value of all samples in one group, and $\mathrm{Cq}$ sample the mean of $\mathrm{Cq}$ values for all samples in one group. Four Excel-based software tools, geNorm, NormFinder, BestKeeper, and Delta Ct, were used to evaluate the expression stability of all candidate reference genes. Moreover, optimal numbers of reference genes required for gene expression normalization were calculated using geNorm. Finally, RefFinder, a web-based tool, provided a comprehensive ranking of selected reference genes.

\subsection{Reference Gene Validation by Analysis of Class III Peroxidase Gene Expression}

In this study, CavPrx [28] was used as a target gene to assess the reliability of the top two potential reference genes, ChaActin and ChaEF1- $\alpha$. The relative expression level of CavPrx at different style flowering stages was determined and normalized using the RT-qPCR conditions described above. Relative expression levels were calculated using the $2^{-\Delta \Delta C t}$ method.

\section{Conclusions}

Stably expressed reference genes are necessary to accurately understand the mechanisms underlying self-incompatibility and identify appropriate SI-related genes. There have been few reports on the search for reference genes for study of hazelnut self-incompatibility. Therefore, we used four different statistical programs and tested the expression stability of 12 selected candidate genes in six sample groups. Our results revealed that ChaActin and ChaEF1- $\alpha$ were the most stably-expressed reference genes for pollen-pistil interaction. These results will benefit future gene expression studies of self-incompatibility, and other genetic research, in Corylus.

Supplementary Materials: The following are available online at https:/ /www.mdpi.com/2223-774 7/10/1/159/s1.

Author Contributions: S.H.: writing—original draft preparation, formal analysis; T.Z.: methodology, data curation; D.Y.: software, validation; Q.L.: visualization; L.L.: investigation; G.W.: resources, 
project administration, funding acquisition; Q.M.: writing-review and editing. All authors have read and agreed to the published version of the manuscript.

Funding: This research was funded by the Special Investigation on Basic Resources of Scienceand Technology (Grant No. 2019FY100801-03) and the Special Fund for Basic Scientific Research Business of Central Public Research Institutes of the Chinese Academy of Forestry, China (CAFYBB2017ZA004-9).

Institutional Review Board Statement: This study did not require ethical approval for not involving humans or animals.

Informed Consent Statement: Not applicable for studies not involving humans.

Data Availability Statement: The data presented in this study are available in supplementary material.

Acknowledgments: The authors sincerely thank the reviewers for their contributions to improve the manuscript during the revision process.

Conflicts of Interest: The authors declare that the research was conducted in the absence of any commercial or financial relationships that could be construed as a potential conflict of interest.

\section{References}

1. Boccacci, P.; Beltramo, C.; Sandoval Prando, M.A.; Lembo, A.; Sartor, C.; Mehlenbacher, S.A.; Torello Marinoni, D. In silico mining, characterization and cross-species transferability of EST-SSR markers for European hazelnut (Corylus avellana L.). Mol. Breed. 2015, 35, 21. [CrossRef]

2. Mehlenbacher, S.A. Advances in genetic improvement of hazelnut. Acta Hortic. 2018, 1226, 12. [CrossRef]

3. Boccacci, P.; Akkak, A.; Botta, R. DNA typing and genetic relations among European hazelnut (Corylus avellana L.) cultivars using microsatellite markers. Genome 2006, 49, 598-611. [CrossRef] [PubMed]

4. Henry, R.J. Wild Crop Relatives: Genomic and Breeding Resources. In Forest Trees; Springer: Berlin, Germany, 2011.

5. Mehlenbacher, S.A. Genetic resources for hazelnut: State of the art and future perspectives. Acta Hortic. 2009, 845, 33-38. [CrossRef]

6. Wang, G.X.; Ma, Q.H.; Zhao, T.T.; Liang, L.S. Resources and production of hazelnut in China. Acta Hortic. 2018, 1226, 59-64. [CrossRef]

7. Zhang, Y.H.; Liu, L.; Liang, W.J.; Zhang, Y.M. Chinese Fruit Tree Records-Chestnut and Hazelnut, In Chinese Fruit Tree Records; China Forestry Publishing House: Beijing, China, 2005.

8. Sathuvalli, V.; Mehlenbacher, S.A. A hazelnut bac library for map-based cloning of a disease resistance gene. Acta Hortic. 2009, 845, 191-194. [CrossRef]

9. Mehlenbacher, S.A.; Brown, R.N.; Davis, J.W.; Chen, H.; Kubisiak, T.L. Rapd markers linked to eastern filbert blight resistance in Corylus avellana. Theor Appl Genet. 2004, 108, 651-656. [CrossRef]

10. Mehlenbacher, S.A.; Smith, D.C. Self-compatible seedlings of the cutleaf hazelnut. HortScience 2006, 41, 482-483. [CrossRef]

11. Mehlenbacher, S.A. Geographic distribution of incompatibility alleles in cultivars and selections of European hazelnut. J. Am. Soc. Hortic. Sci. 2014, 139, 191-212. [CrossRef]

12. Chen, X.; Zhang, J.; Liu, Q.Z.; Guo, W.; Zhao, T.T.; Ma, Q.H.; Wang, G.X. Transcriptome sequencing and identification of cold tolerance genes in hardy Corylus species (C. heterophylla Fisch.) floral buds. PLoS ONE 2014, 9, e108604. [CrossRef]

13. Zhao, T.T.; Zhang, J.; Liang, L.S.; Ma, Q.H.; Chen, X.; Zong, J.W.; Wang, G.X. Expression and functional analysis of WRKY transcription factors in Chinese wild hazel, Corylus heterophylla Fisch. PLoS ONE 2015, 10, e0135315. [CrossRef] [PubMed]

14. Bustin, S.A. Quantification of mRNA using real-time reverse transcription PCR (RT-PCR): Trends and problems. J. Mol. Endocrinol. 2002, 29, 23-29. [CrossRef] [PubMed]

15. Huggett, J.; Dheda, K.; Bustin, S.; Zumla, A. Real-time RT-PCR normalization; strategies and considerations. Genes Immun. 2005 6, 279-284. [CrossRef] [PubMed]

16. Pfaffl, M.W. A new mathematical model for relative quantification in Real-time RT-PCR. Nucleic Acids Res. 2001, 29, e45. [CrossRef] [PubMed]

17. Rubie, C.; Kempf, K.; Hans, J.; Su, T.; Schilling, M. Housekeeping gene variability in normal and cancerous colorectal, pancreatic, esophageal, gastric and hepatic tissues. Mol. Cell. Probes 2005, 19, 101-109. [CrossRef] [PubMed]

18. Hong, S.Y.; Seo, P.J.; Yang, M.S.; Xiang, F.N.; Park, C.M. Exploring valid reference genes for gene expression studies in Brachypodium distachyon by real-time PCR. BMC Plant Biol. 2008, 8, 112. [CrossRef] [PubMed]

19. Bartłomiej, K.; Rapacz, M. Reference genes in real-time PCR. J. Appl. Genet. 2013, 54, 391-406. [CrossRef]

20. Huis, R.; Hawkins, S.; Neutelings, G. Selection of reference genes for quantitative gene expression normalization in flax (Linum usitatissimum L.). BMC Plant Biol. 2010, 10, 71. [CrossRef] [PubMed]

21. Kidd, M.; Nadler, B.; Mane, S.; Eick, G.; Malfertheiner, M.; Champaneria, M.; Pfragner, R.; Modlin, I. Genechip, genorm, and gastrointestinal tumors: Novel reference genes for real-time PCR. Physiol. Genom. 2007, 30, 363-370. [CrossRef]

22. Wan, H.J.; Zhao, Z.G.; Qian, C.T.; Sui, Y.H.; Malik, A.A.; Chen, J. Selection of appropriate reference genes for gene expression studies by quantitative real-time polymerase chain reaction in cucumber. Anal. Biochem. 2010, 399, 257-261. [CrossRef] 
23. Suleman, E.; Somai, B.M. Validation of hish 4 and cox 5 reference genes for RT-qPCR analysis of gene expression in aspergillus flavus under aflatoxin conducive and non-conducive conditions. Microbiol. Res. 2012, 167, 487-492. [CrossRef] [PubMed]

24. Silver, N.; Best, S.; Jiang, J.; Thein, S.L. Selection of housekeeping genes for gene expression studies in human reticulocytes using Real-time PCR. BMC Mol. Biol. 2006, 7, 33. [CrossRef]

25. Thompson, M.M. Genetics of incompatibility in Corylus avellana L. Theor. Appl. Genet. 1979, 54, 113-116. [CrossRef] [PubMed]

26. Li, Q.; Zhao, T.T.; Liang, L.S.; Hou, S.H.; Wang, G.X.; Ma, Q.H. Molecular cloning and expression analysis of hybrid hazelnut (Corylus heterophylla $\times$ Corylus avellana) ChaSRK1/2 genes and their homologs from other cultivars and species. Gene 2020, 756, 144917. [CrossRef] [PubMed]

27. Yang, D. Cloning and Expression Analysis of S Locus Related Gene based on RNA-Seq in Ping'ou Hybrid Hazelnut (Corylus heterophylla Fisch. $\times$ Corylus avellana L.). Master's Thesis, Southwest University, Chongqing, China, 2017.

28. Beltramo, C.; Marinoni, D.T.; Perrone, I.; Botta, R. Isolation of a gene encoding for a class iii peroxidase in female flower of Corylus avellanal. Mol. Biol. Rep. 2012, 39, 4997-5008. [CrossRef] [PubMed]

29. Meng, X.Q. Isolation and Expression Analysis of Floral Genes in Hazelnut. Master's Thesis, Beijing Forestry University, Beijing, China, 2013.

30. Chen, X. De Novo characterization of hazelnut floral bud transcriptome using solexa sequencing and expression profiling analysis of cold-regulated genes. Ph.D. Thesis, Research Institute of Forestry, Chinese Academy of Forestry, Beijing, China, 2011.

31. Vandesompele, J.; De Preter, K.; Pattyn, F.; Poppe, B.; Van Roy, N.; De Paepe, A.; Speleman, F. Accurate normalization of real-time quantitative RT-PCR data by geometric averaging of multiple internal control genes. Genome Biol. 2002, 3, RESESRCH0034. [CrossRef] [PubMed]

32. Zhong, H.Y.; Chen, J.W.; Li, C.Q.; Chen, L.; Wu, J.Y.; Chen, J.Y.; Li, J.G. Selection of reliable reference genes for expression studies by reverse transcription quantitative realtime PCR in litchi under different experimental conditions. Plant Cell Rep. 2011, 30, 641-653. [CrossRef] [PubMed]

33. Liu, D.S.; Shi, L.D.; Han, C.G.; Yu, J.L.; Li, D.W.; Zhang, Y.L. Validation of Reference Genes for Gene Expression Studies in Virus-Infected Nicotiana benthamiana Using Quantitative Real-Time PCR. PLoS ONE 2012, 7, e46451. [CrossRef]

34. Migocka, M.; Papierniak, A. Identification of suitable reference genes for studying gene expression in cucumber plants subjected to abiotic stress and growth regulators. Mol. Breed. 2011, 28, 343-357. [CrossRef]

35. Luo, M.; Gao, Z.; Li, H.; Li, Q.; Zhang, C.X.; Xu, W.P.; Wang, S. Selection of reference genes for miRNA qRT-PCR under abiotic stress in grapevine. Sci. Rep. 2018, 8, 4444. [CrossRef]

36. Robledo, D.; Hernández-Urcera, J.; Cal, R.M.; Pardo, B.G. Analysis of qPCR reference gene stability determination methods and a practical approach for efficiency calculation on a turbot (Scophthalmus maximus) gonad dataset. BMC Genom. 2014, 15, 648. [CrossRef] [PubMed]

37. Xie, F.; Xiao, P.; Chen, D.; Xu, L.; Zhang, B. Mirdeepfinder: A mirna analysis tool for deep sequencing of plant small RNAs. Plant Mol. Biol. Rep. 2012, 80, 75-84. [CrossRef] [PubMed]

38. Xu, S.X.; Wang, D.P.; Yang, D.; Liu, H.S.; Tian, P. Alternative methods to determine infectivity of tulane virus: A surrogate for human nororvirus. Food Microbiol. 2015, 48, 22-27. [CrossRef]

39. David, G.G. Gene quantifcation using real-time quantitative PCR: An emerging technology hits the mainstream. Exp. Hematol. 2002, 30, 503-512. [CrossRef]

40. Xu, J.; Lu, M.X.; Cui, Y.D.; Du, Y.Z. Selection and evaluation of reference genes for expression analysis using qRT-PCR in Chilo suppressalis (lepidoptera: Pyralidae). J. Econ. Entomol. 2017, 110, 683-691. [CrossRef]

41. Dheda, K.; Huggett, J.F.; Chang, J.S.; Kim, L.U.; Bustin, S.A.; Johnson, M.A.; Zumla, A. The implications of using an inappropriate reference gene for real-time reverse transcription PCR data normalization. Anal. Biochem. 2005, 344, 141-143. [CrossRef] [PubMed]

42. Hua, W.; Zhu, J.H.; Shang, Y.; Wang, J.M.; Jia, Q.J.; Yang, J.M. Identification of suitable reference genes for barley gene expression under abiotic stresses and hormonal treatments. Plant Mol. Biol. Rep. 2015, 33, 1002-1012. [CrossRef]

43. Wang, Y.W.; Han, Z.B.; Yan, S.L.; Mao, A.B.; Wang, B.; Ren, H.; Han, Z. Evaluation of suitable reference gene for real-time PCR in human umbilical cord mesenchymal stem cells with long-term in vitro expansion. In Vitro Cell. Dev. Biol. Anim. 2015, 46, 595-599. [CrossRef]

44. Resetic, T.; Stajner, N.; Bandelj, D.; Javornik, B.; Jakse, J. Validation of candidate reference genes in RT-qPCR studies of developing olive fruit and expression analysis of four genes involved in fatty acids metabolism. Mol. Breed. 2013, 31, 211-222. [CrossRef]

45. McInnis, S.M.; Emery, D.C.; Porter, R.; Desikan, R.; Hancock, J.T.; Hiscock, S.J. The role of stigma peroxidases in flowering plants: Insights from further characterization of a stigma-specific peroxidase (SSP) from Senecio squalidus (Asteraceae). J. Exp. Bot. 2006, 57, 1835-1846. [CrossRef]

46. Jiang, T.T.; Gao, Y.H.; Tong, Z.K. Selection of Reference Genes for Quantitative Real-Time PCR in Lycoris. Acta Hortic. Sin. 2015, 42, 1129-1138. [CrossRef]

47. Wang, G.L.; Tian, C.; Jiang, Q.; Xu, Z.S.; Wang, F.; Xiong, A.S. Comparison of nine reference genes for real-time quantitative PCR in roots and leaves during five developmental stages in carrot (Daucus carota L.). J. Hortic. Sci. Biotechnol. 2016, 91, 264-270. [CrossRef]

48. Fang, P.; Lu, R.F.; Sun, F.; Lan, Y.; Shen, W.B.; Du, L.L.; Zhou, T. Assessment of reference gene stability in rice stripe virus and rice black streaked dwarf virus infection rice by quantitative real-time PCR. Virol. J. 2015, 12. [CrossRef] [PubMed] 
49. Zhang, G.; Zhao, M.M.; Zhang, D.W.; Guo, S.X. Reference gene selection for real-time quantitative PCR analysis of dendrobium officinale. J. Chin. Pharm. Sci. 2013, 48, 1664-1668. [CrossRef]

50. Li, J.T.; Han, X.P.; Wang, C.; Qi, W.Z.; Zhang, W.Y.; Tang, L.; Zhao, X. Validation of suitable reference genes for RT-qPCR data in achyranthes bidentata blume under different experimental conditions. Front. Plant Sci. 2017, 8, 776. [CrossRef]

51. Gu, C.; Chen, S.; Liu, Z.; Shan, H.; Luo, H.; Guan, Z.; Chen, F. Reference gene selection for quantitative real-time PCR in Chrysanthemum subjected to biotic and abiotic stress. Mol. Biotechnol. 2011, 49, 192-197. [CrossRef]

52. Sang, J.; Han, X.J.; Liu, M.Y.; Qiao, G.R.; Jiang, J.; Zhuo, R.Y. Selection and validation of reference genes for real-time quantitative PCR in hyperaccumulating ecotype of sedum alfredii under different heavy metals stresses. PLoS ONE 2013, 8, e82927. [CrossRef]

53. Zhu, Y.Y.; Wang, Y.; Zhang, H.; Shao, X.; Li, Y.Q.; Guo, W.D. Selection and characterization of reliable reference genes in Chinese cherry (Prunus pseudocerasus) using quantitative real-time PCR (qRT-PCR). J. Agric. Biotechnol. 2015, 23, 690-700. [CrossRef]

54. Liu, H.; Gao, L.; Hu, Y. Reference Genes Discovery and Selection for Quantitative Real- time PCR in Tree Peony Seed and Petal Tissue of Different Development Stages. J. Agric. Biotechnol. 2015, 23, 1639-1648. [CrossRef]

55. Udvardi, M.K.; Czechowski, T.; Scheible, W.R. Eleven golden rules of quantitative RT-PCR. Plant Cell 2008, 20 , $1736-1737$. [CrossRef]

56. Yan, X.; Dong, X.; Zhang, W.; Yin, H.; Xiao, H.; Chen, P.; Ma, X.F. Reference gene selection for quantitative real-time PCR normalization in Reaumuria soongorica. PLoS ONE 2014, 9, e104124. [CrossRef] [PubMed]

57. Liao, Z.; Chen, M.; Guo, L.; Gong, Y.; Tang, F.; Sun, X.; Tang, K. Rapid isolation of high-quality total RNA from taxus and ginkgo. Prep. Biochem. Biotechnol. 2004, 34, 209-214. [CrossRef] [PubMed]

58. Vandenbroucke, I.I.; Vandesompele, J.; Paepe, A.D.; Messiaen, L. Quantification of splice variants using real-time PCR. Nucleic Acids Res. 2011, 29, e68. [CrossRef] [PubMed]

59. Hoebeeck, J.; van der Luijt, R.; Poppe, B.; De Smet, E.; Yigit, N.; Claes, K.; Vandesompele, J. Rapid detection of VHL exon deletions using real-time quantitative PCR. Lab. Investig. 2004, 85, 24-33. [CrossRef] 